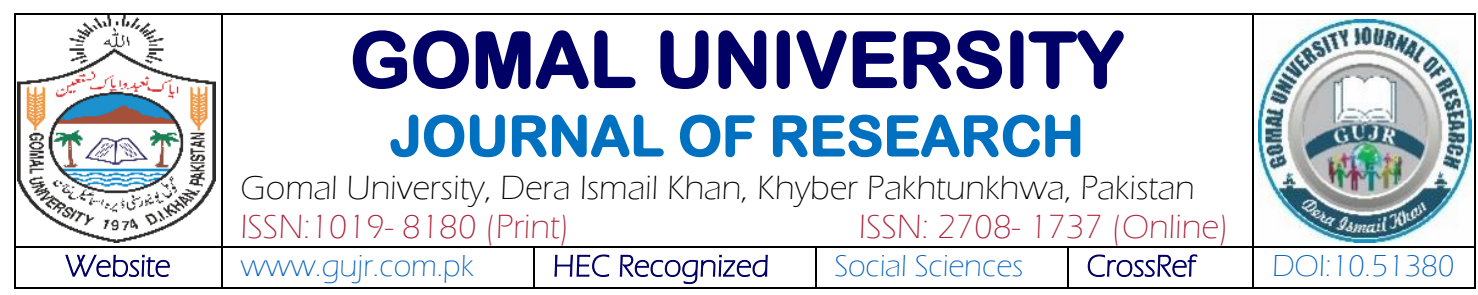

\title{
DO BIG-5 PERSONALITY TRAITS CONTRIBUTE TO EMPLOYEES PERFORMANCE? AN EMPIRICAL EVIDENCE FROM HEIs IN PAKISTAN
}

\author{
Robina Akhtar' , Mohamad Nizam Bin Nazarudin \& Ghulam Muhammad Kundi \\ 'PhD Student Faculty of Psychology and Education, Universiti Malaysia Sabah, MALAYSIA \\ ${ }^{2}$ Faculty of Psychology and Education, The Universiti Malaysia Sabah, Malaysia \\ ${ }^{3}$ College of Public Health, Health Informatics, Al-Bukayriyah, Oassim University, Saudi Arabia
}

\section{KEYWORDS \\ Big-5 Personality, \\ Performance, Teachers \\ $\&$ HEIS}

\section{Article History}

Date of Submission:

09-08-2021

Date of Acceptance:

19-09-2021

Date of Publication:

30-09-2021

\section{ABSTRACT}

Several factors influence the employee's personality including psycho-social

factors. Previously studies have conducted to investigate the influence of Big-5 traits which impact employee's performance. This study investigated the influence of Big-5 on the employee's performance. The study used a cross-sectional survey a 5-point Likert scale was distributed among 163 samples selected randomly. The findings report a significant relationship between the predictors and a criterion variable. The study points those two predictors i.e., openness to experience and emotional control predict 57\% variance in criterion variable as compared to the extravert, agreeableness, and conscientiousness. This study concludes that teacher's centric policies \& mechanisms enhance employee trust and confidence and it overcomes the apprehensions, as result, they perform better and contribute more towards the promotion of education and research in higher educational instiutions.

\begin{tabular}{|c|c|}
\hline & (c) (7) \&) \\
\hline Corresponding Author & Robina Akhtar: alishba.daali@gmail.com \\
\hline $\mathrm{DOI}$ & https://doi.org/10.51380/gujr-37-03-0 1 \\
\hline
\end{tabular}

\section{INTRODUCTION}

The performance of teachers in hiher education institutions squarely depends on their expertise and workplace attributes (Abdullah, Omar, \& Rashid, 2013). The 'organizational behavior' of the teachers is dependent on unlearned and learned personality traits (Barlett \& Anderson, 2012), which are widely studied by social scientists. The role of 'Big-5' personality traits is one of them which determines employee performance. It is a structured composition of personality traits. Studies reported that these factors have convergent and discriminant validity for its instrument used to their impact on the teacher's performance (McCrae \& Costa, 1990). Kumar and Bakhshi (2010) assert that this model is the last word that describes the personality. Accordingly, each of these five traits influences the behavior of teachers (Abdullah, Omar, \& Rashid, 2013). This 
study investigated critical role of 'Big- 5 ' factors in determining the performance of teachers in HEIs.

This study is an effort to investigate the role of the personality attributes on the performance of teachers in the university. The performance of the teachers in Gomal University was measured concerning questions on efficiency, effectiveness, responsiveness, and innovativeness of their profession. The associations between the Big-5 and the performance indicators were explored inter alia the intervention through sample respondents. In this regard, different statistical tools were applied to tests the hypotheses about relationships particularly, correlation and regression. The research says that each of five factors of personality change the organizational behaviors of teachers differently. However, this relationship between personality and performance. In this connection, what is the role of 'Big-5' personality traits in determining the teachers' performance how are it happening in the context of the academicians in HEIs was the main question of this research?

\section{LITERATURE REVIEW}

A psychologist Allport and Odbert (1936) envisioned Big-5 as well as Tupes and Christal (1961) assessed it on 35 scales. McCrae \& Costa (1980) are pioneers who coined the term, they believed that personality traits can be grouped into extraversion, agreeableness, conscientiousness, stability and openness to experience. In this connection, these factors were also recognized by Goldberg (1993) and reoriented them as FFM as the main factors of the personality psychology (Harris \& Fleming, 2017), wherefrom the new era of researching the role and relationship of Big-5 with employee performance got momentum (Jalal, Zeb, \& Fayyaz, 2019; Kim, Karatepe, Lee, Lee, Hur, \& Xijing, 2017; Kundi, Mughal, Albejaidi, \& Pasha, 2021). This means that the Big-5 structure does not only focus on personality differences rather, according to Komarraju, Karau, Schmeck, and Avdic (2011) these five traits represent personality at the broader level and each of these factors summarizes a large number of individuals but more specifically the personality physiognomies.

\section{Extraversion}

A person with extraversion qualities has positive emotions, inspiration and intimacy. It manifests his commitment to external world. An employee with such trait enjoys interaction with other peers, feel excited and practical individuals hence he is considered as action-oriented (Kumar \& Bakhshi, 2010). In this drive, the extrovert is a person who is marked high in extraversion that shows life and lively and enjoy with other employees. Thus, such person participates in social settings with zeal and energy yet in contrast to this approach is person who is low in extraversion that exhibit less outgoing, feel uncomfortable, and prefer to work alone (Jalal, Zeb, \& Fayyaz, 2019).

\section{Agreeableness}

The traits describe the tendency of employee who is compassionate and cooperative. An employee with such quality places priority to get along with his colleagues. Therefore, they are considered thoughtful, lively, sociable, liberal, and accommodating. They also compromise their interests in favor of common good (Babar \& Tahir, 2020). Barlett and Anderson (2012) have reported that an employee who is high at agreeableness is kind, sociable, and considerate. In this regard, on contrary, an employee with a low level of the agreeableness is found uncompromising and unsociable. 


\section{Conscientiousness}

This trait shows the inclination of an employee who is self-disciplined and devoted (Babar \& Tahir, 2020). In this connection, the person with this quality exhibits an inclination for planned behavior. For this determination, Kumar and Bakhshi (2010) assert that an average level of the conscientiousness is generally found in young adults, however, it is hard to find it among older adults.

\section{Openness to Experience}

These traits portray the inclination of an employee who likes arts, adventure, novel ideas, and inquisitiveness. The person who is open to experience has intellectual inquisitiveness, fond of art, and is thoughtful to loveliness. They are more creative and aware of their feelings as compared to closed people. They hold avant-garde beliefs Marzuki (2013), still, openness to experience is vital to support policies and to ensure tolerance. The employee with openness to experience is straightforward.

\section{Neuroticism}

This trait describes the nature of the person who is emotionally unstable and shows annoyance, anxiety, and downheartedness (Babar \& Tahir, 2020), according to Kumar and Bakhshi (2010) it is related to low tolerance for stress thus, an employee with the high level of the neuroticism is emotionally more susceptible to stress and interpret the ordinary situations as threatening, thus this negative reaction persists for long duration. Matthews, Deary, and Whiteman (2003) argue that an employee who score high on the neuroticism display more skin conductance and reaction.

\section{Teachers' Performance}

Employee's performance is defined as his contributions to attainment of organizational goals against the standards and criteria for employee performance (Kundi et al., 2014), which are annually evaluated in HEIs. This as measure of performance facilitates the authorities of HEIs to use the logical approach for identifying the changes well in time (Saklofske, Austin, Mastoras, Beaton, \& Osborne, 2012). Malik, Cao, Mughal, Kundi, Mughal, and Ramayah (2020) have also reported that performance is associated with the attitude and behavior of an employee, which is further supported by Akhtar, Nazarudin, \& Kundi (2021a). Therefore, one of goals of evaluating teacher's performance is distinct the performance levels, enhance the communication between the leadership and teachers, and design and develop the future needs of the training (Akhtar, Nazarudin, \& Kundi (2021b). Recently, it has been recorded that performance assessment is used as a strategic feature that leads to develop plan for teacher's capacity to perform effectively and efficiently (Romel John, Rehana John, \& Zia-ur-Rehman Rao, 2020; Schultz \& Schultz, 2016).

The teacher's performance is determined through their efficiency (Suwanti \& Udin, 2020). It is believed that to enhance efficiency of a teacher, there should be fair competitive race among the employees (Udin \& Ahyar Yuniawan, 2020; Ward, Meade, Allred, Pappalardo, \& Stoughton, 2017). Akhtar, Nazarudin, and Kundi (2021a) are of the view that ideally those HEIs who fail to use their current resources efficiently could not be justified for additional resources. Nguyen and Ngo (2020) and Abdullah, Omar, and Rashid (2013) extends that usually most of HEIs in developing countries lack a proper mechanism to measure the efficiency. Likewise, (Teh, Yong, Chong \& Yew, 2011) contend that effectiveness determines the capability in achieving its goals, 
and a high degree of effectiveness is critical to achieve desired performance. However, Suwanti and Udin (2020) assert that an effective employee fulfills the predefined goals with optimal use of the given resources and deprived of any additional burden on the finances (Nguyen \& Ngo, 2020).

The responsiveness is another determining factor of the performance. The 'responsiveness' is an in-built concept to human psychology, so it captured the attention of researchers to consider it as an indicator of the customer satisfaction (Schultz \& Schultz, 2016; Nguyen \& Ngo, 2020). Saklofske, Austin, Mastoras, Beaton and Osborne (2012) considered timely response as a critical success factor. Similarly, Suwanti and Udin (2020) suggest that enhancing the responsiveness and capacity of teachers in HEIs to respond quickly. Without innovation modern organizations could not survive, therefore, creativity and innovation play a vital role in successful and fail management (Kumar \& Bakhshi, 2010). The innovative ideas help materialize the effectiveness, efficiency and responsiveness (Suwanti \& Udin, 2020). Thus, it demands changes in the human resource system to be more flexible, dynamic, and open (Udin \& Ahyar, 2020). However, due to red tape and bureaucratization, any notion that might be beneficial for the transformation and change is resisted and discouraged in HEIs, efforts are made to oppose such ideas that could bring innovation. Ward, Meade, Allred, Pappalardo and Stoughton (2017) are of opinion that to achieve enhanced level of the performance, HEIs needs to follow innovative, open and adaptive practices.

\section{Theoretical Support}

Findings of previous studies show that Big-5 personalities explicate an array of human behavior i.e., job satisfaction, commitment, trust, turnover intention and work performance. Rammstedt and John (2007) put forward that Big-5 personality factors significantly teacher's willingness to accept an assignment and work. Similarly, Rast and Tourani (2012) reported that personality traits (Big-5) significantly predict teacher's performance. Likewise, Seng, Theng, Ling, Siang, and Yean (2013), Singh and Singh (2009), and Soto, Kronauer and Liang (2015) reported similar results yet, Fuller, Hester and Cox, (2010); Darsana, (2013); Abdullah, Omar and Rashid, (2013); Bhatti, Battour, Ismail and Sundram, (2014); Harris and Fleming, (2017); Dong and Phuong, (2018); Jalal, Zeb, and Fayyaz, (2019) and Babar and Muhammad, (2020) reported significant relationship between personality constructs and teachers' performance. Based on findings of the studies conducted earlier, model of this study developed, and hypotheses were proposed. The schematic presentation of the theoretical model is developed from review of previous studies, this picturesque explains relationship of independent variables (IV) with dependent variables (DV).

\section{Research Hypotheses}

The predictors (Big-5 personality traits) are significantly associated with criterion variable $\left(\mathrm{H}_{1}\right)$. The Big-5 personality traits significantly predicts and explain the teachers' performance $\left(\mathrm{H}_{2}\right)$.

\section{Theoretical Framework}

The theoretical framework offered the schematic diagram representing the research variables wherein the arrows shows the potential reltionships among research variables. According to this model (framework), extroversion, agreeableness, conscientiousness, neuroticism and openness to experience are the significant factors which determines various dimensions of the teacher's performance. 
Figure 1

Schematic Diagram of Theoretical Framework

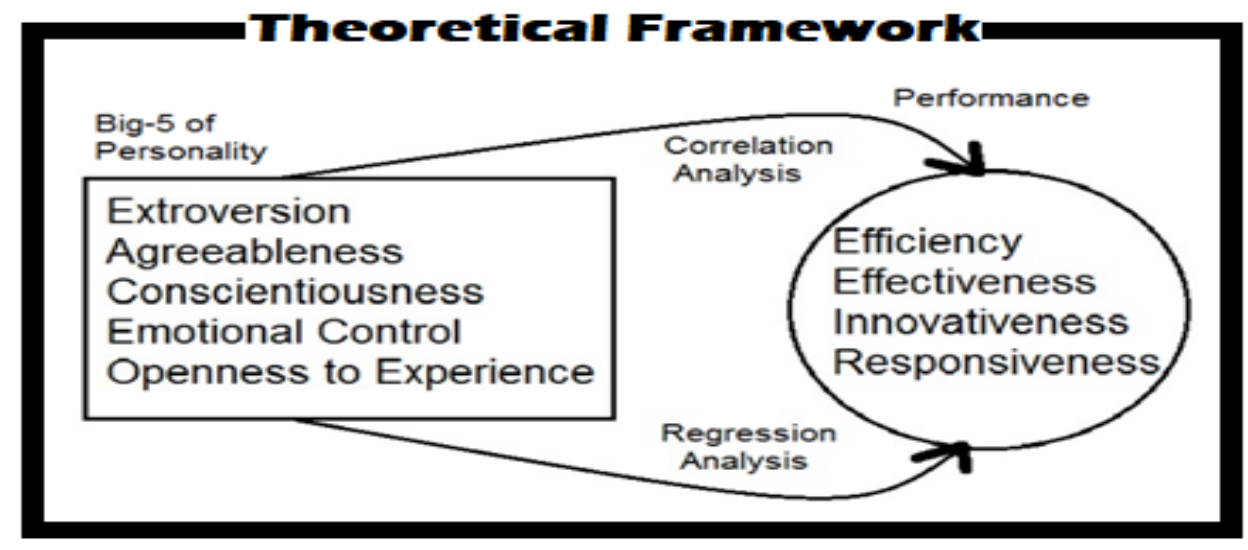

\section{RESEARCH METHODOLOGY}

The study has employed quantitative cross-sectional design suggested by Babbie (2004) and Yin, (2009) subsequently, survey is considered the finest tool that measures attitudes and behavioral orientations (Sekaran, 2016) of the population of interest. The population of the study included the teachers from Gomal University, Dera Ismail Khan, and table-1 gives a birds-eye view of the population.

Table 1

Population of Study

\begin{tabular}{lc}
\hline \multicolumn{2}{c}{ Teachers at Gomal University } \\
\hline Professor & 09 \\
Associate Professor & 12 \\
Assistant Professor & 155 \\
Lecturer & 141 \\
\hline Population (N) & 317 \\
\hline
\end{tabular}

The sample size was determined through $\mathrm{n}=[\sigma 2 /(\mathrm{E} 2 / \mathrm{Z2}+\sigma 2 / \mathrm{N})]($ Weiers, 1984). A structured questionnaire was used consisted of nine factors with 38 items. The items were measured on 5 points Likert scale, the options were ranging from Strongly Disagree $=1$ to Strongly Agree $=5$.

\section{Table 2}

Sampling \& Sample Size

\begin{tabular}{lc}
\hline formula $=[\sigma 2 /(\mathrm{E} 2 / \mathrm{Z} 2+\sigma 2 / \mathrm{N})]$ & $\mathrm{n}$ \\
\hline$[0.9972 /(0.9722 / 1.962+0.9972 / 317)]$ & 162.2245 \\
\hline
\end{tabular}

\section{RESULTS OF STUDY}

The results of study is presented in this section as outcomes of the statistical procedure to reach conclusion. 


\section{Reliability of Scale}

Hulin, Netemeyer and Cudeck (2001) suggested 0.6 as the minimum acceptable value for alpha reliability for the generalizability and acceptability. In this connection, aggregate alpha score (.855) for all the factors was recorded above the accepted value of .06 which is presented in the table 3 .

\section{Table 3}

Cronbach Alpha Score

\begin{tabular}{ccc}
\hline Items & Statements & Cronbach alpha \\
\hline 09 & 38 & .855 \\
\hline
\end{tabular}

\section{Descriptive Analysis}

Table 4 illustrates 4.29 for 'extroversion' as a powerful factor in the model and 3.71 has been computed for performance as the weakest average, likewise, the second-largest average is shown by agreeableness i.e., 4.12. This implies that the extroversion and agreeableness of teachers are significant factors of the model among the rest of the factors.

Table 4

Descriptive Statistics on Research Variables

\begin{tabular}{cccccc}
\hline Variables & $\mathrm{n}$ & Min & Max & Mean & SD \\
\hline EXV & 163 & 1 & 5 & 4.2902 & .76634 \\
AGB & 163 & 1 & 5 & 4.1248 & .65527 \\
CST & 163 & 1 & 5 & 3.9832 & .66427 \\
ECT & 163 & 1 & 5 & 4.0111 & .70673 \\
OTE & 163 & 1 & 5 & 3.8966 & .83553 \\
PER & 163 & 1 & 5 & 3.7133 & .53195 \\
\hline Valid n (list-Wise) & 163 & & & & \\
\hline
\end{tabular}

Abbreviations: extraversion [EXV], agreeableness [AGB], conscientiousness [CST], emotional control [ECT] control, openness to experience [OTE], performance [PER].

\section{Testing of Hypotheses}

H1 was related to association among the research variables (Gig-5 personality traits \& teachers' performance), the thus, correlation was run in SPSS 23, the output is presented in the table- 5 $(n=163)$.

\section{Table 5}

Correlation Results for $\mathrm{H1}$

\begin{tabular}{llccccc}
\hline & & EXV & AGB & CST & ECT & OTE \\
\hline Agreeableness & $\mathrm{R}$ & $.512^{* *}$ & & & & \\
AGB & P-value & .000 & & & & \\
& $\mathrm{n}$ & 163 & & & & \\
Conscientiousness & $\mathrm{R}$ & $.505^{* *}$ & $.386^{* *}$ & & \\
CST & $\mathrm{P}$-value & .000 & .000 & & \\
& $\mathrm{n}$ & 163 & 163 & & \\
Emotional Control & $\mathrm{R}$ & $.479^{* *}$ & $.444^{* *}$ & $.569^{* *}$ &
\end{tabular}


Akhtar et al ... Do Big-5 Personality

\begin{tabular}{llccccc} 
ECT & P-value & .000 & .000 & .000 & & \\
& $\mathrm{n}$ & 163 & 163 & 163 & & \\
Control, Openness & $\mathrm{R}$ & $.512^{* *}$ & $.273^{* *}$ & $.372^{* *}$ & $.406^{* *}$ & \\
to Experience OTE & $\mathrm{P}$-value & .000 & .000 & .000 & .000 & \\
& $\mathrm{n}$ & 163 & 163 & 163 & 163 & \\
Performance & $\mathrm{R}$ & $.359^{* *}$ & $.294^{* *}$ & $.385^{* *}$ & $.406^{* *}$ & $.445^{* *}$ \\
PER & $\mathrm{P}$-value & .000 & .000 & .000 & .000 & .000 \\
\hline & $\mathrm{n}$ & 163 & 163 & 163 & 163 & 163
\end{tabular}

**. Correlation is significant at the 0.01 level (2-tailed).

*.Correlation is significant at the 0.05 level (2-tailed).

Table 5 highlights that highest correlation is found between variables, i.e., EXV and 'performance' are positively correlated i.e., $\mathrm{r} .359^{* *}$ at 0.000 level of significance, Similarly, AGB .294**, CST .385 , ECT .406, ETE .445 have also significant and positive association with performance. This implies hundred percent significance of relationship for all of computations. So, we accept our hypothesis that independent variables and dependent variables are significantly related to one another.

Table 6

Variables Entered and Removed for $\mathrm{H} 2$

\begin{tabular}{cccl}
\hline Model & Entered & Removed & Methods \\
\hline 1 & OTE &. & $\begin{array}{l}\text { Stepwise (Criteria: Probability-of-F-to-enter }<=.050, \\
\text { Probability-of-F-to-remove }>=.100) .\end{array}$ \\
\hline 2 & ECT &. & $\begin{array}{l}\text { Stepwise (Criteria: Probability-of-F-to-enter }<=.050, \\
\text { Probability-of-F-to-remove }>=.100) .\end{array}$ \\
\hline
\end{tabular}

a. Dependent Variable: Performance

Table 7

Model Summary for $\mathrm{H} 2$

\begin{tabular}{ccccc}
\hline Model & $\mathrm{R}$ & $\mathrm{R} 2$ & Adjusted R2 & SE of the Estimate \\
\hline 1 & $.447 \mathrm{a}$ & .578 & .491 & .47877 \\
\hline 2 & $.512 \mathrm{~b}$ & .553 & .566 & .46205 \\
\hline
\end{tabular}

Predictors: (Constant), OTE, Predictors: (Constant), OTE, ECT

Table 8

ANOVA for $\mathrm{H}_{2}$

\begin{tabular}{|c|c|c|c|c|c|c|}
\hline \multicolumn{2}{|c|}{ Model } & Sum of Squares & $\mathrm{df}$ & Mean Square & $\mathrm{F}$ & Sig. \\
\hline \multirow[t]{3}{*}{1} & Regression & 8.751 & 1 & 8.542 & 39.618 & $.000 \mathrm{a}$ \\
\hline & Residual & 34.994 & 161 & .238 & & \\
\hline & Total & 43.744 & 162 & & & \\
\hline \multirow[t]{3}{*}{2} & Regression & 11.398 & 2 & 5.644 & 27.852 & $.000 \mathrm{~b}$ \\
\hline & Residual & 32.456 & 159 & .215 & & \\
\hline & Total & 43.744 & 162 & & & \\
\hline
\end{tabular}

Predictors: (Constant), OTE, Predictors: (Constant), OTE, ECT, Dependent Variable: Performance 
Table 9

Excluded Variables for H2

\begin{tabular}{clccccc}
\hline & Model & Beta & $\mathrm{t}$ & Sig. & Partial Correlation & Collinearity Statistics \\
\hline 1 & EXV & $.187 \mathrm{a}$ & 2.288 & .062 & .180 & .748 \\
& AGB & $.196 \mathrm{a}$ & 2.687 & .060 & .201 & .936 \\
& CST & $.265 \mathrm{a}$ & 3.561 & .021 & .274 & .872 \\
& ECT & $.279 \mathrm{a}$ & 3.717 & .000 & .285 & .846 \\
2 & EXV & $.099 \mathrm{~b}$ & 1.161 & .206 & .093 & .661 \\
& AGB & $.124 \mathrm{~b}$ & 1.476 & .124 & .109 & .795 \\
\hline & CST & $.174 \mathrm{~b}$ & 1.962 & .052 & .154 & .663
\end{tabular}

Predictors in the Model: (Constant), OTE, Predictors in the Model: (Constant), OTE, ECT Dependent Variable: Performance

Table 10

Coefficients for $\mathrm{H}_{2}$

\begin{tabular}{|c|c|c|c|c|c|c|}
\hline \multicolumn{2}{|c|}{ Model } & \multicolumn{2}{|c|}{$\begin{array}{c}\text { Unstandardized } \\
\text { Coefficients }\end{array}$} & \multirow{2}{*}{$\begin{array}{c}\begin{array}{c}\text { Standardized } \\
\text { Coefficients }\end{array} \\
\text { Beta }\end{array}$} & \multirow[t]{2}{*}{$\mathrm{t}$} & \multirow[t]{2}{*}{ Sig. } \\
\hline & & B & SE & & & \\
\hline \multirow[t]{2}{*}{1} & (Constant) & 2.624 & .187 & & 13.737 & .000 \\
\hline & OTE & .282 & .046 & .456 & 6.397 & .000 \\
\hline \multirow[t]{3}{*}{2} & (Constant) & 2.186 & .235 & & 9.365 & .000 \\
\hline & OTE & .223 & .067 & .347 & 4.589 & .000 \\
\hline & ECT & .198 & .056 & .274 & 3.612 & .000 \\
\hline
\end{tabular}

Dependent Variable: Performance

The multiple regression results are given in tables 6 to 10, which indicate OTE and ECT being powerful factors explains $57 \%(\mathrm{R} 2=.578)$ variance teacher's PER, whereas Beta value for OTE is recorded .456 which is higher than the ECT. The results also show that EXV and AGB (.062, and .060) have no role in predicting the teacher's performance since they fall in the excluded variables with their p-values less than the acceptable value i.e., .050 which is recommended for decisions at a 95\% level of confidence. Therefore, with R2 of 57\%, second hypothesis is partially accepted.

\section{DISCUSSION}

Personality is a complex and unpredictable phenomenon reflected by an employee in a unique situation. Personality is only biological makeup, but it includes attitude and behavior (Udin, \& Ahyar, 2020). To understand the personality experts, focus on its composition i.e., trait theory and social learning theory. From an organizational perspective, it is more critical to understand those aspects which are related to individual performance, measured by individual efficiency, effectiveness, responsiveness and innovation (Ucho et al., 2012; Li, 2011). Personality is closely related to the teacher's performance. Teachers who exhibit a higher level of extroversion takes interest in work and assignments (Barlett \& Anderson, 2012; Han, 2020; Askarian \& Eslami, 2013; Darsana, 2013). To check association between predictors and criterion variables, it was hypothesized that predictors are significantly associated with one another. The reported result supports our assumption since positive and significant association was found among variables 
of this study thus our results are consistent with Harris and Fleming (2017) and Jalal, Zeb, and Fayyaz (2019). Fuller, Hester and Cox (2010) argues that Big-5 personality is strongest factor that define personality and determine performance, this claim is supported by Babar and Tahir (2020).

Furthermore, highest correlation is found in the study between the variables, likewise EXV and 'performance' are positively correlated i.e., r $.359^{* *}$ at 0.000 level of the ignificance, Similarly, AGB .294**, CST .385, ECT .406, ETE .445 have also significant and positive association with the performance, which suggested the acceptance of $\mathrm{H} 1$. This implies hundred percent significance of the relationship for all of computations. Likewise, two predictors out of factors were found significant likewise, OTE and ECT which explained 57\% (R2 = 0. 578) 57\% variance teacher's performance, furthermore, OTE was reported as the most powerful with a Beta score of .456 followed by ECT. Marzuki (2013) also reported its prominent role in defining the employee's performance this implies that an employee with the trait in contrast to a closed person is more creative with a high level of awareness, this suggested the acceptance of hypothesis for impact of Big-5 personality traits in the performance, i.e., H2. Komarraju, Karau, Schmeck, and Avdic (2011) have reported that closed individuals prefer familiarity over novelty hence change is resisted by such personalities, their findings are aligned with that of the Rammstedt and John (2007).

This research has identified that ETV, AGR, and CON have no role in predicting the teacher's performance. Thus, the findings of this study are inconsistent with Li (2011); Bakhshi (2010); Askarian and Eslami (2013); Cervone and Pervin (2013); Bhatti, Battour, Ismail, and Sundram (2014); Harris and Fleming (2017); Dong and Phuong (2018); Jalal, Zeb, and Fayyaz (2019), and Han (2020). The inconsistency of the findings might be due to the contextual difference of the settings where this study is conducted in developing country and previous studies reported results from the developed countries (Matin, Kalali, \& Anvari, 2012). The personality is closely related to the teacher's performance. Teachers who exhibit a higher level of extroversion takes interest in work and assignments. Though Pakistani is progressing with the humble pace ahead towards in all sectors especially the higher education is mushrooming with reasonable growth rate and considerable increase literacy and education, is evident from the Pakistan Economic Surveys (2019-2020) however, yet it possesses characteristics of society as well as of transitional society, that have the strong routes in the people psyche. This demands the congenial working environment.

This study suggests that management of HEIs must ensure a friendly environment if they wish enhanced performance from their teachers (Cervone \& Pervin, 2013; Bhatti, Battour, Ismail, \& Sundram, 2014; Dong \& Phuong, 2018). Similarly, changes in norms and values also increase the complexity due to which achieving the pre-defined objectives using archaic methods, tools, and procedures are impossible, consequently like, Li (2011) and Kumar and Bakhshi (2010) recommended tailor-made changes consistent with local conditions. Higher education around the globe is witnessing reforms to enhance capacity, capability and broaden the vision of their teachers. Askarian and Eslami (2013) reports the current assignments of the university teachers are teaching and research. The study was conducted with this dynamic background to investigate the significant role of Big-5 personality factors in defining the teacher's performance in HEIs. Teachers are the knowledge workers and have a different role from physical workers (Bhatti, Battour, Ismail, \& Sundram, 2014), therefore society expects greater performance from teachers 
as uniform and consistent performance is required for success of the academics and research excellence.

\section{CONCLUSION}

HEIs are high seats of learning and play a greater role in nation's development and prosperity. Teacher's competence, experience, commitment and satisfaction contribute to accomplishment goals; so, teachers are key to success. It is concluded that extrovert teachers are more sociable and energetic, they are adventurous and enthusiastic. Also, forgiving teachers are straightforward and demonstrate agreeableness. The self-disciplined and organized teachers are dutiful and efficient. On other hand, irritable, depressed, and shy lack emotional stability. This finds that extroversion, agreeableness, and conscientiousness have no role to predict teacher performance yet openness to experience and emotional control were reported to have a significant impact on the performance. The majority of proposed hypotheses have been substantiated but some were partially accepted. This study recommends that HEIs must provide the congenial and learning environment so teachers can unlearn old beliefs and values and learn the new ones. The study recommends the application of democratic and participative approaches at the workplace with culture of tolerance and patience. Emotional stability is essential for effective teaching- learning process to resolve issues of deviant behavior exhibited by young learners. The cross-culture for change in psyche and breakup of cognitive maps are required to part of the policy together with adequate motivation. The study explored teachers in HEIs so results could only be generalized to HEIs inter alia, it was conducted in developing country, and result could be useful for HEIs in developing.

\section{REFERENCES}

Abdullah, I., Omar, R., \& Rashid, Y. (2013). Effect of personality on organizational commitment and employees' performance: Empirical Evidence from Banking Sector of Pakistan. Middle East Journal of Scientific Research, 18(6), 759-766.

Akhtar, R., Nazarudin, M. N., \& Kundi, G. M. (2021). Empirical evidence on the mediating role of job satisfaction, commitment, trust in leadership, intention to leave amid leadership styles, performance appraisal, and physical education teacher's performance. Psychology and Education, 58(4), 729- 38.

Akhtar, R., Nazarudin, M. N., \& Kundi, G. M. (2021). Reversing paradigm: Empirical evidence of followership in shaping transactional leadership style, mediating effect of trust, leadermember exchange (LMX). Psychology and Education. 58(5), 422- 433.

Albejaidi, F., Kundi, G. M., \& Mughal, Y. H. (2020). Decision-making, leadership styles and leadership effectiveness: An AMOS-SEM approach. African Journal of Hospitality, Tourism, and Leisure, 9(1), 1-15.

Allport, G. W., \& Odbert, H. S. (1936). Trait-names: A psycho-lexical study. Psychological Monographs, 47(211).

Ashkanasy, N. M., Troth, A. C., Lawrence, S. A., \& Jordan, P. J. (2017). Emotions and emotional regulation in HRM: A Multi-Level perspective. Research in Personnel and Human Resources Management, 35, 1-52.

Askarian, N., \& Eslami, H. (2013). The relationship between personality traits and job performance (Case Study: Employees of Ministry of Education of Kerman). Interdisciplinary Journal of Contemporary Research in Business, 5(8), 322-335. 
Babar, M., \& Tahir, M. (2020). The effects of big five personality traits on employee job performance among university lecturers in Peshawar city. International Journal of Management \& Entrepreneurship Research, 2(1), 43-50.

Babbie, Earl, R. (2004). The practice of social research. New York: Thomson/Wadsworth Publishers.

Barlett, C. P., \& Anderson, C. A. (2012). Direct and indirect relations between Big-5 personality traits and aggressive and violent behavior. Personality, and Individual Differences, 52, 870-875.

Bhatti, M. A., Battour, M. M., Ismail, A. R., \& Sundram, V. P. (2014). Effects of personality traits (big five) on expatriates adjustment and job performance. Equality, Diversity, and Inclusion: An International Journal, 33(1), 73-96.

Cervone, D., \& Pervin, L. (2013). Personality: Theory and research. New York, NY: Wiley and Sons.

Cooper, A. J., Smillie, L. D., \& Corr, P. J. (2010). A confirmatory factor analysis of the Mini-IPIP five-factor model personality scale. Personality and Individual Differences, 48(5), 688-691.

Darsana, M. (2013). The influence of personality and organizational culture on employee performances through organizational citizenship behavior. The International Journal of Management, 2(4), 35-42.

Dong, L. T., \& Phuong, D. (2018). Organizational justice, job satisfaction and organizational citizenship behavior in higher education institutions: A research proposition in Vietnam. Journal of Asian Finance, Economics, and Business, 5(3), 113-119.

Fuller, B., Hester, K., \& Cox, S. S. (2010). Proactive personality and job performance: Exploring job autonomy as a moderator. Journal of Managerial Issues, 35-51.

Goldberg, L. R. (1993). The structure of phenotypic personality traits. American Psychologist, $48,26-34$.

Han, J. H. (2020). The effects of personality traits on subjective well-being and behavioral intention associated with serious leisure experiences. Journal of Asian Finance, Economics, and Business, 7(5), 167-176.

Harris, E. G., \& Fleming, D. E. (2017). The productive service employee: personality, stress, satisfaction, and performance. Journal of Services Marketing, 31(6), 499-511.

Hulin, C., Netemeyer, R., \& Cudeck, R. (2001). Can a Reliability Coefficient be too high? Journal of Consumer Psychology, 10(1), 55-58.

Jalal, R. D., Zeb, N., \& Fayyaz, U. R. (2019). The effect of personality traits on employee job satisfaction with moderating role of Islamic work ethics. Journal of Asian Finance, Economics and Business, 6(2), 161-171.

Kang, M., \& Sung, M. (2017). How symmetrical employee communication leads to employee engagement and positive employee communication behaviors: The mediation of employee-organization relationships. Journal of Communication Management, 21(1), 82-102.

Kim, T. T., Karatepe, O. M., Lee, G., Lee, S., Hur, K., \& Xijing, C. (2017). Does hotel employees' quality of work-life mediate the effect of psychological capital on job outcomes? International Journal of Contemporary Hospitality Management, 29(6), 1638-1657.

Komarraju, M., Karau, S. J., Schmeck, R. R., \& Avdic, A. (2011). The Big Five personality traits, learning styles, and academic achievement. Personality and Individual Differences, 51(4), 472-477. 
Kumar, K., \& Bakhshi, A. (2010). The five-factor model of personality and organizational commitment: Is there any relationship? Humanity \& Social Sciences Journal, 5(1), 25-34.

Kundi, G. M., Mughal, Y. H., Albejaidi, F., \& Pasha, S. A. (2021). An empirical study on the job satisfaction and turnover intention of healthcare professionals: Moderated moderation approach. International Journal of Health Science, 15(4), 10-19.

Malik, S. Y., Cao, Y., Mughal, Y. H., Kundi, G. M., Mughal, M. H., \& Ramayah, T. (2020). Pathways towards sustainability in organizations: Empirical evidence on the role of green human resource management practices and green intellectual capital. Sustainability, 12(8), 1-24.

Marzuki, N. A. (2013). The impact of personality on employee well-being. European Scientific Journal, 9(20), 43-52.

Matin, H. Z., Kalali, N. S., \& Anvari, M. R. (2012). Do demographic variables moderate the relationship between job burnout and its consequences? Iranian Journal of Management Studies, 5(1), 47-62

Matthews, G., Deary, I. J., \& Whiteman, M. C. (2003). Personality traits, 4th Ed. Cambridge University Press.

McCrae, R. R., \& Costa, P. T. (1999). A five-factor theory of personality. In: L. Pervin, \& O. John (Eds.), Handbook of personality: Theory and research. 2nd Ed., New York, Guilford Press. pp. 139-153.

Nawaz, A., \& Kundi, G. M. (2010b). Demographic implications for the eLearning user perceptions in HEIs of NWFP, Pakistan. Electronic Journal of Information Systems for Developing Countries, 41(5), 117-128.

Nguyen, H.M., \& Ngo, T.T. (2020). Psychological capital, organizational commitment, and job performance: A Case in Vietnam. Journal of Asian Finance, Economics, and Business, $7(5), 269-278$.

Rammstedt, B., \& John, O.P. (2007). Measuring personality in one minute or less: A 10 item short version of the Big Five Inventory in English and German. Journal of Research in Personality, 41, 203-212.

Rast, S., \& Tourani, A. (2012). Evaluation of employees' job satisfaction and role of gender difference: An empirical study at airline industry in Iran. International Journal of Business and Social Science, 3(7): 91-100.

Romel, J., Rehana, J., \& Rehman, A. R. (2020). The Big Five personality traits and academic performance. Journal of Law \& Social Studies, 2(1), 10-19.

Saklofske, H., Austin, E. J., Mastoras, S. M., Beaton, L., \& Osborne, S. E. (2012). Relationships of personality, affect emotional intelligence and coping with student stress and academic success: Different patterns of association for stress and success. Learning and Individual Differences, 22(2), 251-257.

Schultz, D.P., \& Schultz, S.E. (2016). Theories of personality. Cengage Learning.

Sekaran, U., \& Roger, J. Bougie. (2016). Research Methods for Business: A Skill Building Approach. 7th Ed. Wiley. P. 257.

Seng, C. C., Theng, C. S., Ling, L. S., Siang, T. T., \& Yean, W. B. (2013). The effect of big five personalities on job performance: Job autonomy as the moderator (Bachelor Thesis), Universiti Tunku Abdul Rahman, Malaysia.

Singh, A. K., \& Singh, A. P. (2009). Does personality predict organizational citizenship behavior among managerial personnel? Journal of the Indian Academy of Applied Psychology, 35(2), 291-298. 
Soto, C. J., Kronauer, A., \& Liang, J. K. (2015). Five-factor model of personality. John Wiley \& Sons, Inc.

Suwanti, S., \& Udin, U. (2020). Investigating the relationship between person-organization fit, person-job fit, and innovative work behavior: The mediation role of organizational citizenship behavior. Quality-Access to Success, 21(176).

Teh, P.L., Yong, C.C., Chong, C.W., \& Yew, S.Y. (2011). Do the Big Five personality factors affect knowledge-sharing behavior? A study of Malaysian universities. Malaysian Journal of Library \& Information Science, 16(1), 47-6.

Tupes, E.C., \& Christal, R.E. (1961). Recurrent personality factors based on trait ratings (USAF ASD Tech. Rep. No. 61-97). Lackland Air Force Base, TX: U.S. Air Force.

Ucho, A., Mkavga, M., \& Onyishi, I.E. (2012). Job satisfaction, gender, tenure, and turnover intentions among civil servants in Benue State. Interdisciplinary Journal of Contemporary Research in Business, 3(11), 378-387.

Udin, U., \& Ahyar, Y. (2020). Psychological capital, personality traits of Big-Five, organizational citizenship behavior, and task performance: Testing their relationships. Journal of Asian Finance, Economics and Business, 7(9), 781-790.

Ward, M. K., Meade, A. W., Allred, C. M., Pappalardo, G., \& Stoughton, J. W. (2017). Careless response and attrition as sources of bias in online survey assessments of personality traits and performance. Computers in Human Behavior, 76, 417-430.

Weiers, R. M. (1984). The Marketing Research. Englewood Cliffs, NJ: The Prentice-Hall. P. 126.

Yin, R. K. (2009). Case Study Research: Design and Methods. 4th Ed. Thousand Oaks, CA: Sage. P. 26. 